\title{
Multiple isotope analyses of the pike tapeworm Triaenophorus nodulosus reveal peculiarities in consumer-diet discrimination patterns
}

\author{
J. Behrmann-Godel and E. Yohannes* \\ Limnological Institute, University of Konstanz, Mainaustrasse 252, \\ D-78464, Konstanz, Germany
}

(Received 10 May 2013; Accepted 28 November 2013; First Published Online 22 January 2014)

\begin{abstract}
Previous studies of dietary isotope discrimination have led to the general expectation that a consumer will exhibit enriched stable isotope levels relative to its diet. Parasite-host systems are specific consumer-diet pairs in which the consumer (parasite) feeds exclusively on one dietary source: host tissue. However, the small numbers of studies previously carried out on isotopic discrimination in parasite-host $\left(\Delta \mathrm{X}_{\mathrm{P}-\mathrm{HT}}\right)$ systems have yielded controversial results, showing some parasites to be isotopically depleted relative to their food source, while others are enriched or in equilibrium with their hosts. Although the mechanism for these deviations from expectations remains to be understood, possible influences of specific feeding niche or selection for only a few nutritional components by the parasite are discussed. $\Delta \mathrm{X}_{\mathrm{P}-\mathrm{HT}}$ for multiple isotopes $\left(\delta^{13} \mathrm{C}\right.$, $\delta^{15} \mathrm{~N}, \delta^{34} \mathrm{~S}$ ) were measured in the pike tapeworm Triaenophorus nodulosus and two of its life-cycle fish hosts, perch Perca fluviatilis and pike Esox lucius, within which T. nodulosus occupies different feeding locations. Variability in the value of $\Delta X_{P-H T}$ calculated for the parasite and its different hosts indicates an influence of feeding location on isotopic discrimination. In perch liver $\Delta \mathrm{X}_{\mathrm{P}-\mathrm{HT}}$ was relatively more negative for all three stable isotopes. In pike gut $\Delta \mathrm{X}_{\mathrm{P}-\mathrm{HT}}$ was more positive for $\delta^{13} \mathrm{C}$, as expected in conventional consumer-diet systems. For parasites feeding on pike gut, however, the $\delta^{15} \mathrm{~N}$ and $\delta^{34} \mathrm{~S}$ isotope values were comparable with those of the host. We discuss potential causes of these deviations from expectations, including the effect of specific parasite feeding niches, and conclude that $\Delta \mathrm{X}_{\mathrm{P}-\mathrm{HT}}$ should be critically evaluated for trophic interactions between parasite and host before general patterns are assumed.
\end{abstract}

\section{Introduction}

Stable isotope methodology, and in particular the use of stable isotope values of carbon $\left(\delta^{13} \mathrm{C}\right)$, nitrogen $\left(\delta^{15} \mathrm{~N}\right)$ and, more recently, sulphur $\left(\delta^{34} \mathrm{~S}\right)$ have proved useful in investigating organismal trophic ecology. Interpretation of stable isotope ratios is generally based on the observation that there is typically an isotopic difference

*E-mail: Elizabeth.yohannes@uni-konstanz.de between the ratios of $\delta^{15} \mathrm{~N}$ and $\delta^{13} \mathrm{C}$ found in the tissues of a consumer and in its diet, such that heavy isotopes are enriched higher up the food chain. These discrepancies, known as isotopic discrimination or fractionation factors, typically translate to a standard enrichment of approximately $+3 \%$ or for $\delta^{15} \mathrm{~N}$ and $+1 \%$ o for $\delta^{13} \mathrm{C}$ at each tropic level. In contrast, analyses of $\delta^{34} \mathrm{~S}$ ratios in consumers raised on controlled diets suggested that there is little or no discrimination associated with the incorporation of sulphurous amino acids into consumer tissues 
(e.g. Minagawa \& Wada, 1984; Vander Zanden \& Rasmussen, 2001; Post, 2002; Richards et al., 2003).

Parasite-host systems are specialized consumer-diet pairs in which the parasite, by definition, feeds exclusively on its host's tissues (Kennedy, 1976). This exclusivity suggests that parasite-host systems should present textbook examples of stable isotope discrimination. Based on accepted norms for the isotopic relationship between a consumer and its diet (or a predator and its prey), and with the assumption that parasites feed directly on bulk tissues of their hosts, we would expect parasites to be isotopically enriched in comparison to their diet (Doucett et al., 1999). Indirect feeding on metabolic byproducts such as mucus or blood (e.g. Gresty \& Quarmby, 1991) should also result in isotopic enrichment of the parasite.

However, previous studies applying stable isotope analysis to parasite-host systems have often reported patterns of discrimination that confound expectations. Some results conform to the standard consumer-diet discrimination model, showing enrichment of $\delta^{15} \mathrm{~N}$ and $\delta^{13} \mathrm{C}$ in parasites relative to their hosts (e.g. Doucett et al., 1999), but others show mixed patterns, such as depletion in one form of stable isotope and enrichment in another (e.g. Boag et al., 1998; Neilson \& Brown, 1999). Among fish host-parasite systems, nematodes and cestodes exhibit depleted $\delta^{15} \mathrm{~N}$ relative to their hosts, while parasitic copepods and isopods appear isotopically depleted and enriched, respectively, compared with their host fish (Iken et al., 2001; Pinnegar et al., 2001; Deudero et al., 2002; Power \& Klein, 2004; Xu et al., 2007; Navarro et al., 2013). These and further confounding data gathered from other parasite-host systems (Neilson et al., 2005; O'Grady \& Dearing, 2006) suggest that the isotopic signatures of parasites do not always fit with the consumer-diet discrimination pattern seen in other trophic systems.

It is possible that the stable isotope signatures of parasites might vary depending on factors such as the specific feeding location of the parasite or the ontogenetic stage and nutritional status of the hosts. Such factors may contribute to considerable variability in the isotopic signatures of parasite infrapopulations (after Bush et al., 1997) and also between parasites feeding in different locations on various types of host tissue. To test these concepts, we investigated relative values of three stable isotopes $\left(\delta^{13} \mathrm{C}, \delta^{15} \mathrm{~N}\right.$ and $\left.\delta^{34} \mathrm{~S}\right)$ in the pike tapeworm Triaenophorus nodulosus collected from two different lifecycle hosts within which the parasite adopts different feeding locations.

Triaenophorus nodulosus is a pseudophyllidean cestode with an indirect life cycle incorporating three obligate hosts in the course of approximately 1 year (Kuperman, 1973). In spring, adult worms resident in pike (Esox lucius) intestines reproduce, and eggs are shed into the water along with the host faeces (fig. 1). The new generation of tapeworms hatches into a free-living ciliated stage (coracidium) which is short lived. Cyclopoid copepods become infected through ingestion of coracidia and the parasites develop to the fish-infective stage (procercoid) in the copepod's haemocoel. For further parasitic transmission, the infected copepods must be ingested by the second intermediate host, a planktivorous fish. Perch, Perca fluviatilis, are a typical host, but the flatworm
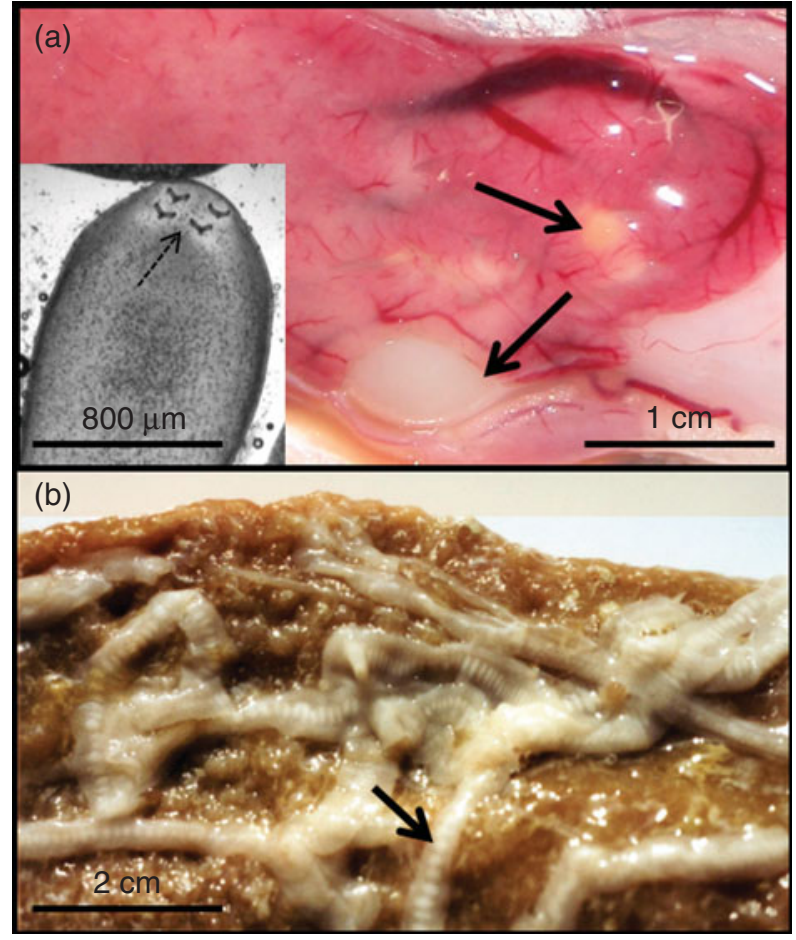

Fig. 1. (a) Perch liver with encysted T. nodulosus (arrowed) plus inset with the plerocercoid removed from the cyst to show the four typical hooks (arrowed) on the scolex. (b) Adult T. nodulosus with gravid proglottids (arrowed) from the pike intestine. Photo by A. Brinker.

can also infect a wide range of other fish species (Kuperman, 1973). Ingested procercoids migrate to the liver where they are encysted by the tissues of their second host (fig. 1) and develop to the next infective stage, the hook-bearing plerocercoid. Final transmission to the definitive host occurs when pike feed on infected fish.

The present study compares the stable isotope values of three elements $\left(\delta^{13} \mathrm{C}, \delta^{15} \mathrm{~N}\right.$ and $\left.\delta^{34} \mathrm{~S}\right)$ in parasite tissues with those of their respective host's tissues, using T. nodulosus plerocercoids from perch liver and adult T. nodulosus from pike intestines. The aim of our study was to test whether: (1) general expectations from consumer-diet discrimination patterns (in which heavy stable isotopes are enriched in the consumer) hold for parasite-host systems of T. nodulosus and its fish hosts, irrespective of the parasite's location in the host; or (2) the parasitic consumer-diet discrimination pattern varies with respect to the specific feeding location (host tissue or organ) of the parasite (T. nodulosus).

\section{Materials and methods}

\section{Sampling procedures}

Adult perch were collected in November 2011and April 2012 from littoral zones of Lake Constance (Germany), using gill nets of 28 - or $32-\mathrm{mm}$ bar mesh size. In the laboratory, fish were dissected and livers were removed. Liver cysts were opened carefully and all hook-bearing 
T. nodulosus plerocercoids were removed and washed in water. Most plerocercoids were too small for individual isotope analysis; therefore, entire infrapopulations from every individual perch (between 2 and 13 worms each) were combined to make isotope analysis samples. Four T. nodulosus infrapopulations were analysed in 2011 and eight in 2012.

In April 2012, 12 individual adult T. nodulosus were sampled from the gut of two pike (six worms from each host), caught by fishermen in Lake Constance. These worms were analysed individually, being large enough to make one sample for stable isotope analysis. Samples of muscle tissue and gut contents were also collected from the two pike hosts.

\section{Stable isotope procedures}

Stable isotope $\left(\delta^{13} \mathrm{C}, \delta^{15} \mathrm{~N}\right.$ and $\left.\delta^{34} \mathrm{~S}\right)$ analyses were conducted on all parasites, host tissues and gut contents. Tissue samples were dried, and powdered subsamples of approximately $0.7-1 \mathrm{mg}$ were weighed to the nearest $0.001 \mathrm{mg}$ in small tin cups, using a micro-analytical balance. Samples were then combusted in a vario Micro cube elemental analyser (Elementar, Analysensysteme, Hanau, Germany). The resulting $\mathrm{CO}_{2}, \mathrm{~N}_{2}$ and $\mathrm{SO}_{2}$ were separated by gas chromatography and passed into the inlet of a Micromass (Manchester, UK) Isoprime isotope ratio mass spectrometer (IRMS) for determination of ${ }^{13} \mathrm{C} /{ }^{12} \mathrm{C},{ }^{15} \mathrm{~N} /{ }^{14} \mathrm{~N}$ and ${ }^{36} \mathrm{~S} /{ }^{34} \mathrm{~S}$ ratios. Measurements are reported in $\delta$-notation $\left(\delta^{13} \mathrm{C}, \delta^{15} \mathrm{~N}\right.$ and $\delta^{34} \mathrm{~S}$, respectively) where $\delta=1000 \times$ $\left(\mathrm{R}_{\text {sample }} / \mathrm{R}_{\text {standard }}\right)-1 \%$, relative to the Pee Dee Belemnite (PDB) standard for carbon, and atmospheric $\mathrm{N}_{2}$ for nitrogen, in parts per thousand deviations (\%o). Two sulphanilamides (Isoprime internal standards calibrated and traceable to NBS-127 barium sulphate, $\delta^{34} \mathrm{~S}=+20.3 \%$ o) and two casein standards were used for every ten unknowns in sequence. Internal laboratory standards indicated measurement errors (SD) of $\pm 0.05 \%$, $0.15 \%$ o and $0.05 \%$ for $\delta^{13} \mathrm{C}, \delta^{15} \mathrm{~N}$ and $\delta^{34} \mathrm{~S}$, respectively.

For all samples collected in 2012, lipids were removed from each homogenized sample by rinsing in 2:1chloroform:methanol solution for $24 \mathrm{~h}$, then rinsing in distilled water before conducting stable isotope analysis. Lipid extraction was necessary because levels of ${ }^{13} \mathrm{C}$ in lipids are depleted relative to whole organism or tissue ${ }^{13} \mathrm{C}$ values; and variations in the lipid content of animal tissue samples (Peterson \& Fry, 1987; Kling et al., 1992) may therefore bias the isotope signatures.

\section{Data analysis}

Isotopic differences between hosts and parasites (host-parasite discrimination factors) were estimated by subtracting the parasite isotope value from that of its respective host tissue:

$$
\Delta \mathrm{X}=\delta \mathrm{X}_{\mathrm{P}}-\delta \mathrm{X}_{\mathrm{HT}}
$$

where $X$ is ${ }^{13} \mathrm{C},{ }^{15} \mathrm{~N}$ or ${ }^{34} \mathrm{~S}$ for parasite $(\mathrm{P})$ and host tissue (HT) (i.e. liver, gut content or muscle sample).

Pairwise comparisons of the stable isotope signatures of each perch liver and its corresponding parasite infrapopulation were conducted for each sampling year using paired $t$ - tests $(\alpha=0.05)$, after confirming normality and homogeneity of variance (Shapiro-Wilk test; each element and each year tested separately). If one of the tests revealed a significant difference, Mann-Whitney Rank Sum Tests were performed (Sokal \& Rohlf, 2000).

Compared with $\delta^{13} \mathrm{C}$ results, $\delta^{15} \mathrm{~N}$ values appear relatively unaffected by lipid-content bias, with limited evidence for differences in $\delta^{15} \mathrm{~N}$ between untreated and treated samples (Ingram et al., 2007; Logan et al., 2008). There is no detailed evidence on the effect of lipid extraction on $\delta^{34} \mathrm{~S}$ values in aquatic consumers. Therefore, we also compared pooled data for $\delta^{15} \mathrm{~N}$ and $\delta^{34} \mathrm{~S}$ for 2011 and 2012.

An independent one-sample $t$-test was used to ascertain whether average pike-cestode isotope values differed significantly from those of host gut content or muscle tissues. Stable isotope values of host gut content, muscle, or mean values thereof, were used as test variables. A Mann-Whitney Rank Sum Test was used to compare the isotope signatures of $T$. nodulosus sampled from perch and pike.

\section{Results}

Mean \pm standard error (SE) for all stable isotope values and results of the $t$-test or Mann-Whitney rank sum test are given in table 1 . On average, parasites showed isotopic depletion for most of the elements analysed. However, individual pairwise host-parasite comparisons revealed various kinds of associations, including isotopic enrichment or depletion of parasites as well as isotopic equivalency in the signatures of host and parasite. Additionally, plerocercoid infrapopulations of T. nodulosus and perch liver showed a wide range of stable isotope values for all three elements. For example, approximate values of $\delta^{13} \mathrm{C}$ for perch livers and T. nodulosus ranged from $-24 \%$ to $-30 \%$ and c. $-28 \%$ o to $-32 \%$, respectively.

Mean \pm standard error (SE) and results of the onesample $t$-tests for each stable isotope and tissue are given in table 2 . In terms of $\delta^{13} \mathrm{C}$, parasites showed isotopic enrichment with respect to both host gut content (mean $\Delta^{13} \mathrm{C}=+2.68$ ) and host muscle tissue (mean $\left.\Delta^{13} \mathrm{C}=+2.25\right)$. Parasite $\delta^{15} \mathrm{~N}$ values, however, were similar to those obtained from gut content or muscle tissue (mean gut content $\Delta^{15} \mathrm{~N}=0.39$; mean muscle $=\Delta^{15} \mathrm{~N}=-0.32$ ), while their mean $\Delta^{34} \mathrm{~S}$ gut content and muscle values were -0.48 and +0.16 , respectively.

Finally, T. nodulosus collected from pike gut and perch liver in 2012 were significantly different, showing higher values in the pike for $\delta^{13} \mathrm{C}(t=-36.00, P<0.001)$ and $\delta^{15} \mathrm{~N}(t=114.00, P=0.02)$, but not for $\delta^{34} \mathrm{~S}(t=82.00$, $P=0.91)$.

\section{Discussion}

\section{Parasite-host stable isotope discrimination patterns}

The paired host-parasite multiple stable isotope values obtained in our study exhibited a full spectrum of discrimination patterns, including relative depletion, enrichment and isotopic equilibrium in the three different elements analysed (tables 1 and 2). This implies that expectations based on the consumer-diet discrimination hypothesis, wherein consumer (parasite) values of $\delta^{13} \mathrm{C}$ and $\delta^{15} \mathrm{~N}$ would be enriched compared to those of the diet 
Table 1. Mean \pm SE values of carbon, nitrogen and sulphur isotopes of Triaenophorus nodulosus, in the liver of perch in 2011 and 2012 and discrimination factors. Number of T. nodulosus infrapopulations analysed is given in parentheses. Paired and independent $t$-tests and a Mann-Whitney rank sum test are given for each comparison, with significant difference as $P<0.05^{*}$, and unequivalent sample sizes are due to missing samples.

\begin{tabular}{|c|c|c|c|c|c|c|}
\hline Year & $\delta^{13} \mathrm{C}(\%$ \% $)$ & Test & $\delta^{15} \mathrm{~N}(\%$ o $)$ & Test & $\delta^{34} \mathrm{~S}(\%$ & Test \\
\hline T. nodulosus & $-30.95 \pm 0.13(4)$ & $t=-3.54$ & $12.80 \pm 0.47(3)$ & $t=0.13$ & $6.92 \pm 0.68(3)$ & $t=1.48$ \\
\hline$\Delta \mathrm{X}_{\mathrm{P}-\text { Liver }}$ & $-4.08 \pm 1.04$ & & $+0.13 \pm 0.57$ & & $1.40 \pm 0.69$ & \\
\hline \multicolumn{7}{|l|}{2012} \\
\hline T. nodulosus & $-29.78 \pm 0.57(8)$ & $t=-3.54$ & $13.88 \pm 0.31(8)$ & $t=-4.06$ & $4.32 \pm 0.53(8)$ & $t=2.69$ \\
\hline Liver & $-28.64 \pm 0.32$ & $P=0.06$ & $15.01 \pm 0.15(8)$ & $P<0.001^{*}$ & $5.37 \pm 0.28(8)$ & $P=0.01^{*}$ \\
\hline \multicolumn{7}{|l|}{2011 and 2012} \\
\hline T. nodulosus & $-30.17 \pm 0.57(12)$ & $t=-3.30$ & $13.58 \pm 0.30(11)$ & $t=-2.64$ & $5.03 \pm 0.55(11)$ & $t=-0.99$ \\
\hline Liver & $-28.00 \pm 0.49(12)$ & $P=0.01^{*}$ & $14.37 \pm 0.40(11)$ & $P=0.02^{*}$ & $5.41 \pm 0.25(11)$ & $P=0.39$ \\
\hline$\Delta \mathrm{X}_{\mathrm{P} \text {-Liver }}$ & $-2.11 \pm 0.64(12)$ & & $-0.78 \pm 0.16$ & & $-0.39 \pm 0.43(11)$ & \\
\hline
\end{tabular}

(host), do not generally hold for all T. nodulosus-fish host systems. But we do find support for the hypothesis in that the isotopic signature of the parasite is influenced by the specific life-cycle stage or the feeding location of the parasite in its host. For instance, $\delta^{13} \mathrm{C}$ showed a negative discrimination in perch (liver) but exhibited significant enrichment in the two pike tissues tested (gut content and muscle). Most T. nodulosus plerocercoid infrapopulations from the perch liver were depleted in all three stable isotopes compared with the host liver tissue, whereas T. nodulosus from pike intestine showed equivalency, minor enrichment or depletion of $\delta^{15} \mathrm{~N}$ and $\delta^{34} \mathrm{~S}$ compared with host gut content or muscle tissue.

All parasites used in this study were either in the late plerocercoid stage (encysted, hook-bearing worms in the liver of perch) or the adult stage (carrying ripe proglottids in the intestine of pike) and must have been resident in the host for a minimum of 6 months before being sampled (fig. 1). Thus, stable isotope signatures are unlikely to have been biased by previous host values.

We studied T. nodulosus parasitizing the liver of perch and the intestine of pike. The liver plays a major role in metabolism and has several important physiological functions, including glycogen synthesis, storage and breakdown of metabolites, plasma protein synthesis and the destruction of senescent red blood cells. In the intestine, hydrolysis of various carbohydrates takes place. Triaenophorus nodulosus should be able to utilize a variety of metabolic resources in both locations. Therefore, one could expect that, irrespective of location, T. nodulosus will absorb nutrients (mainly glucose) directly across its tegument (Kuperman, 1973; Barrett, 1981), resulting in an enriched isotopic signature (Gresty \& Quarmby, 1991). We found variability in isotopic discrimination and thus conclude that plerocercoids and adult worms of T. nodulosus may feed on nutritional resources other than

Table 2. Mean \pm SE values of carbon, nitrogen and sulphur isotopes of Triaenophorus nodulosus in pike and discrimination factors. Number of T. nodulosus analysed is given in parentheses. Independent $t$-tests are given for each comparison, with a significant difference as $P<0.05^{*}$, and unequivalent sample sizes are due to missing samples.

\begin{tabular}{|c|c|c|c|c|c|c|}
\hline Specimen & $\delta^{13} \mathrm{C}(\%)$ & Test & $\delta^{15} \mathrm{~N}(\%)$ & Test & $\delta^{34} S(\% \circ)$ & Test \\
\hline \multicolumn{7}{|l|}{ Pike 1} \\
\hline T. nodulosus & $-26.73 \pm 0.09(6)$ & & $13.03 \pm 0.06(6)$ & & $4.75 \pm 0.04(6)$ & \\
\hline$\Delta \mathrm{X}_{\mathrm{P}-\mathrm{Gut}}$ content & $+2.47 \pm 0.09(6)$ & $P<0.001^{*}$ & $+0.20 \pm 0.06(6)$ & $P=0.02^{*}$ & $-0.57 \pm 0.04(6)$ & $P<0.001^{*}$ \\
\hline Muscle & -28.69 & $t=21.07$ & 13.43 & $t=-6.36$ & 4.81 & $t=-1.40$ \\
\hline$\Delta \mathrm{X}_{\mathrm{P}-\text { Muscle }}$ & $+1.92 \pm 0.09(6)$ & $P<0.001^{*}$ & $-0.39 \pm 0.06(6)$ & $P=0.001^{*}$ & $-0.05 \pm 0.04(6)$ & $P=0.22$ \\
\hline \multicolumn{7}{|l|}{ Pike 2} \\
\hline$\Delta \mathrm{X}_{\mathrm{P}-\mathrm{Gut}}$ content & $+2.89 \pm 0.07(6)$ & $P<0.001^{*}$ & $+0.58 \pm 0.05(6)$ & $P<0.001^{*}$ & $-0.38 \pm 0.04$ & $P<0.001^{*}$ \\
\hline Muscle & -29.27 & $t=38.22$ & 13.42 & $t=-4.30$ & 4.54 & $t=9.52$ \\
\hline$\Delta \mathrm{X}_{\mathrm{P}-\mathrm{Muscle}}$ & $+2.58 \pm 0.07(6)$ & $P<0.001^{*}$ & $-0.25 \pm 0.05(6)$ & $P=0.01^{*}$ & $+0.37 \pm 0.04(6)$ & $P<0.001^{*}$ \\
\hline \multicolumn{7}{|l|}{ Pike 1 and 2} \\
\hline T. nodulosus & $-26.73 \pm 0.05(12)$ & & $13.10 \pm 0.04(12)$ & & $4.83 \pm 0.03(12)$ & \\
\hline Gut content & $-29.41 \pm 0.17(2)$ & $t=48.27$ & $12.71 \pm 0.11(2)$ & $t=8.62$ & $5.31 \pm 0.01(2)$ & $t=-13.25$ \\
\hline
\end{tabular}


bulk host-tissues. Moreover, a host-tissue response to T. nodulosus in perch liver leads to encapsulation of plerocercoids within a relatively thick cyst wall (fig. 1a). This cyst wall probably functions as a diffusion barrier and may hinder the direct uptake of glucose and other nutrients, resulting in depletion of stable isotope values as compared with the surrounding host liver tissue.

Since parasitic cestodes have a limited ability to synthesize carbohydrates de novo or to undertake gluconeogenesis, they are obliged to obtain the simple carbohydrates required for the biosynthesis of complex products from their hosts (Bryant \& Behm, 1989; Tielens \& Van Hellemond, 2006). Additionally, while the host is the principal source of essential amino acids, parasitic flatworms are known to synthesize some amino acids for themselves, in particular large quantities of proline. These unusual aspects of flatworm biology might contribute to the observed disparities with conventional isotope discrimination values.

\section{Variation in stable isotope discrimination patterns in different life-cycle hosts}

In pike, we found a positive $\Delta^{13} \mathrm{C}_{\mathrm{P}-\mathrm{HT}}$ in both gut content and muscle tissues. These conform to the expected pattern of stable isotope discrimination between a consumer and its diet. While the condition of muscle (or liver) tissues represents isotopic integration over time with respect to nutrient input (e.g. weeks to months), gut contents give a point-in-time 'snapshot' of consumption, reflecting only substances ingested by the host immediately prior to capture (i.e. within a few hours). No undigested fish material was observed in our study samples from pike gut, but the hydrolysed gut contents presumably contain free glucose. However, the pike gut content and muscle tissue samples collected for this study exhibited identical isotope signatures for the three isotopes considered. This implies low variation in the short- and long-term dietary choices of host pike, which may feed faithfully on the same diet throughout the season. Interestingly, the $12 \mathrm{~T}$. nodulosus individuals collected from pike hosts over two sampling years exhibited highly consistent and repeatable isotopic signatures for all the elements investigated (SE range: 0.04-0.09, table 1). This indicates similar feeding behaviour of parasites (and presumably also of hosts) and a lack of individual variation of the mechanism of nutrient assimilation from a common nutrient source. We acknowledge, however, that our sample size may mask potential variations that might be found with a much larger study. Another striking result was that the $\delta^{15} \mathrm{~N}$ and $\delta^{34} \mathrm{~S}$ values of gut content, muscle and the parasites extracted from pike gut were identical, indicating an isotopic equilibrium between host gut contents and muscle, as well as between parasite and host.

In contrast, the stable isotope values found for perch and their $T$. nodulosus plerocercoid infrapopulations varied significantly compared with those for pike and their adult T. nodulosus parasites. A number of physiological and environmental factors could explain the wide variations of signatures within perch and its parasites. Such differences include life-history stage or seasonal or ontogenic changes in diet and/or metabolism, leading to different isotopic values in host tissues (e.g. Cocheret de la Morinière et al., 2003).

However, in this study, all perch were females within the adult size range, caught during the cold season. Thus gender, ontogenetic stage or seasonal changes in diet are unlikely to explain the variation in isotope values observed. We believe that the range of isotopic values in perch is most probably a reflection of individual differences in diet. Perch are generalist feeders, well known to take a wide variety of food organisms. Individual specializations in specific food items have been shown in this fish species (Svanbäck \& Eklöv, 2004). Thus, although adult perch in Lake Constance are expected to be mainly piscivorous, a variety of alternative food items have been identified, including planktonic and benthic prey (Schleuter \& Eckmann, 2008). The variation of isotopic values of T. nodulosus plerocercoid infrapopulations most probably mirrors the individual variability in the diet of their perch host.

To conclude, this study has quantified isotope differences between cestode parasites and their intermediate and definitive fish hosts using a triple isotope approach. We report individual patterns of isotopic hostparasite discrimination ranging from depletion, through no change, to enrichment for the three elements analysed. Additionally, the results illustrate host-tissue specific isotopic discrimination values. The variability and lack of general pattern documented in this study could be partly a result of variable field conditions; and the use of only bulk liver, muscle and gut content as a dietary proxy. If, instead of feeding on the bulk tissue of their host, flatworm parasites assimilate only specific host-derived bio-substrates, such as glucose or amino acids, the isotopic composition of the parasites will be based only on those particular nutrient components. Thus, caution is necessary in applying discrimination values to isotope data collected exclusively from natural populations. Further experimental studies on host-parasite isotope differences, which require hosts to be fed on controlled diets of known isotopic signature under laboratory conditions, are to be desired. Thus far, host-parasite isotope studies have generally considered only $\delta^{13} \mathrm{C}$ and $\delta^{15} \mathrm{~N}$ values. Sulphur isotopes have hardly been examined in fish, but our data suggest that, as in $\delta^{13} \mathrm{C}$ and $\delta^{15} \mathrm{~N}$, $\delta^{34} \mathrm{~S}$ also varies and thus further study of this element may add to our understanding of trophic interactions between parasites and hosts. Additional investigations of the role of differential assimilation of dietary components by parasites, for example using compound-specific stable isotope analysis on specific host body fluids and other tissues, might give a better insight into this system.

\section{Acknowledgements}

We appreciate the help of Pierre Tichit and Saskia Rehse during sample preparation and isotope analysis. We acknowledge Amy-Jane Beer for commenting on the manuscript.

\section{Financial support}

E.Y. and J.B.-G. were supported by the University of Konstanz, Institute for Limnology and by the 'Stiftung für 
Umwelt und Wohnen' of the University of Konstanz, respectively.

\section{Conflict of interest}

None.

\section{References}

Barrett, J. (1981) Biochemistry of parasitic helminths. 380 pp. London, MacMillan.

Boag, B., Neilson, R., Robinson, D., Scrimgeour, C.M. \& Handley, L.L. (1998) Wild rabbit host and some parasites show trophic-level relationships for delta ${ }^{13} \mathrm{C}$ and delta ${ }^{15} \mathrm{~N}$ : a first report. Isotopes in Environmental and Health Studies 34, 81-85.

Bryant, C. \& Behm, C. (1989) Biochemical adaptations in parasites. 259 pp. London, Chapman \& Hall.

Bush, A.O., Lafferty, K.D., Lotz, J.M. \& Shostak, W. (1997) Parasitology meets ecology on its own terms: Margolis et al. revisited. Journal of Parasitology 83, 575-583.

Cocheret de la Morinière, E., Pollux, B.J.A., Nagelkerken, I., Hemminga, M.A., Huiskes, A.H.L. \& van der Velde, G. (2003) Ontogenic dietary changes of coral reef fishes in the mangrove- seagrass- reef continuum: stable isotopes and gut-content analysis. Marine Ecology. Progress Ser. 246, 279-289.

Deudero, S., Pinnegar, J.K. \& Polunin, N.V. (2002) Insights into fish host-parasite trophic relationships revealed by stable isotope analysis. Disease of Aquatic Organisms 7, 77-86.

Doucett, R., Giberson, D. \& Power, G. (1999) Parasitic association of Nanocladius (Diptera: Chironomidae) and Pteronarcys biloba (Plecoptera: Pteronarcyidae): insights from stable-isotope analysis. Journal of the North American Benthological Society 18, 514-523.

Gresty, K.A. \& Quarmby, C. (1991) The trophic level of Mytilicola intestinalis Steuer (Copepoda: Poecilostomatoida) in Mytilus edulis L., as determined from stable isotope analysis. Proceedings of the Fourth International Conference on Copepoda. Bulletin of the Plankton Society of Japan Special volume, 363-371.

Iken, K., Brey, T., Wand, U., Voigt, J. \& Junghans, P. (2001) Food web structure of the benthic community at the Porcupine Abyssal Plain (NE Atlantic): a stable isotope analysis. Progress in Oceanography 50, 383-405.

Ingram, T., Mathews, B., Harrod, C., Stephens, T., Grey, J. \& Markel, R. (2007) Lipid extraction has little effect on the $\delta^{15} \mathrm{~N}$ of aquatic consumers. Limnology and Oceanography Methods 5, 338-343.

Kennedy, C.R. (1976) Ecological aspects of parasitology. 474 pp. Amsterdam, North Holland Publishing.

Kling, G.W., Fry, B. \& O’Brien, W.J. (1992) Stable isotopes and planktonic trophic structure in arctic lakes. Ecology 73, 561-566.

Kuperman, B.I. (1973) Tapeworms of the genus Triaenophorus - parasites of fish. 222 pp. New Delhi, India, Amerind Publication.

Logan, J.M., Jardine, T.D., Miller, T.J., Bunn, S.E., Cunjak, R.A. \& Lutcavage, M.E. (2008) Lipid corrections in carbon and nitrogen stable isotope analyses: comparison of chemical extraction and modeling methods. Journal of Animal Ecology 77, 838-846.

Minagawa, M. \& Wada, E. (1984) Stepwise enrichment of ${ }^{95} \mathrm{~N}$ along food chains: further evidence and the relation between $\delta^{15} \mathrm{~N}$ and animal age. Geochimica et Cosmochimica Acta 48, 1135-1140.

Navarro, J., Albo-Puigserver, M., Coll, M., Saez, R., Forero, M.G. \& Kutcha, R. (2013) Isotopic discrimination of stable isotopes of nitrogen $\left(\delta^{15} \mathrm{~N}\right)$ and carbon $\left(\delta^{13} \mathrm{C}\right)$ in a host-specific holocephalan tapeworm. Journal of Helminthology doi:10.1017/ S0022149X13000126.

Neilson, R. \& Brown, D.J.F. (1999) Feeding on different host plants alters the natural abundances of $\delta^{13} \mathrm{C}$ and $\delta^{15} \mathrm{~N}$ in Longidoridae (Nemata). Journal of Nematology 31, 20-26.

Neilson, R., Boag, B. \& Hartely, G. (2005) Temporal hostparasite relationships of the wild rabbit, Oryctolagus cuniculus (L.) as revealed by stable isotope analyses. Parasitology 131, 279-285.

O'Grady, S.P. \& Dearing, M.D. (2006) Isotopic insight into host-endosymbiont relationships in Liolaemid lizards. Oecologia 150, 355-361.

Peterson, B.J. \& Fry, B. (1987) Stable isotopes in ecosystem studies. Annual Review of Ecology and Systematics 18, 293-320.

Pinnegar, J., Campbell, N. \& Polunin, N. (2001) Unusual stable isotope fractionation patterns observed for fish host-parasite trophic relationships. Journal of Fish Biology 59, 494-503.

Post, D.M. (2002) Using stable isotopes to estimate trophic position: models, methods, and assumptions. Ecology 83, 703-718.

Power, M. \& Klein, G. (2004) Fish host-cestode parasite stable isotope enrichment patterns in marine, estuarine and freshwater fishes from northern Canada. Isotopes in Environmental Health Studies 40, 257-266.

Richards, M.P., Fuller, B.T., Sponheimer, M., Robinson, T. \& Ayliffe, L. (2003) Sulphur isotopes in palaeodietary studies: a review and results from a controlled feeding experiment. International Journal of Osteoarchaeology 13, 37-45.

Schleuter, D. \& Eckmann, R. (2008) Generalist versus specialist: the performances of perch and ruffe in a lake of low productivity. Ecology of Freshwater Fish 17, 86-99.

Sokal, R.R. \& Rohlf, F.J. (2000) Biometry. 3rd edn. New York, W.H. Freeman.

Svanbäck, R. \& Eklöv, P. (2004) Morphology in perch affects habitat specific feeding efficiency. Functional Ecology 18, 503-510.

Tielens, A.G.M \& Van Hellemond, J.J. (2006) Unusual aspects of metabolism in flatworm parasites. pp. 387-405 in Maule, A.G. \& Narks, J.N. (Eds) Parasitic flatworms: molecular biology, biochemistry, immunology and physiology. King's Lynn, Biddles Ltd.

Vander Zanden, M.J. \& Rasmussen, J.B. (2001) Variation in delta $\mathrm{N}-15$ and delta $\mathrm{C}-13$ trophic fractionation: Implications for aquatic food web studies. Limnology and Oceanography 46, 2061-2066.

Xu, J., Zhang, M. \& Xie, P. (2007) Trophic relationship between the parasitic isopod Ichthyoxenus japonensis and the fish Carassius auratus auratus as revealed by stable isotopes. Journal of Freshwater Ecology 22, 238-333. 